\title{
CHANGES IN MACRONUTRIENT CONCENTRATIONS IN SOIL SOLUTION FOLLOWING REGENERATION FELLING IN PINE AND SPRUCE STANDS: WHOLE-TREE HARVESTING VERSUS STEM-ONLY HARVESTING
}

Ivars KLAVINS, Latvian State Forest Research Institute 'Silava', Address: 111 Rigas str, Salaspils, LV-2169, Latvia; ivars.klavins@silava.lv (corresponding author)

Arta BARDULE, Latvian State Forest Research Institute 'Silava', Address: 111 Rigas str, Salaspils, LV-2169, Latvia; arta.bardule@ silava.lv

Zane LIBIETE, Latvian State Forest Research Institute 'Silava', Address: 111 Rigas str, Salaspils, LV-2169, Latvia; zane.libiete@silava.lv

\begin{abstract}
While conventional forest management in boreal and hemiboreal conditions has traditionally been targeted to use and enhance mainly provisioning services like timber production, the main goal of national and European forest policy is to ensure sustainable management of European forests in all aspects. Regeneration felling is a major disturbance in boreal and hemiboreal forests resulting in significant increase of organic matter on the forest floor in the form of logging residues (bark, small branches, tree tops) and severed roots (in case of stump harvesting), and can increase the risk of nutrient leaching. Recently, concern about the effect of forest management impact on macronutrient leaching potentially decreasing nutrient availability for the next forest generations and causing deterioration of water quality has been raised. In 2011, three objects to study the impact of different intensity regeneration felling (stem-only harvesting and whole-tree harvesting) were established in scientific research forests in Kalsnava forest district, eastern part of Latvia. Two sites were located on mineral soils (Myrtillosa and Hylocomiosa site type, dominant tree species Pinus sylvestris L.) and one on drained peat soil (Oxalidosa turf. mel. site type, dominant tree species Picea abies (L.) Karst.). Felling was performed in early spring 2013 with harvester, timber was extracted and logging residues were removed with forwarder, following "business as usual" principle. Soil solution samples were collected once or twice a month in 2012, 2013, 2014, 2015 and 2016. This study presents trends of $\mathrm{pH}$ and macronutrient ( $\mathrm{NO}_{3}{ }^{-}-$ $\left.\mathrm{N}, \mathrm{PO}_{4}{ }^{3-}-\mathrm{P}, \mathrm{K}\right)$ concentrations during five years - one year before harvesting and four years following harvesting. In general, significant forest management impact expressed as increase of macronutrient concentrations in soil solution was detected in the second and third year after harvesting, but in the fourth year concentrations started to decrease again.
\end{abstract}

Keywords: Intensive forest management, macronutrients, Norway spruce, Scots pine, soil solution

\section{INTRODUCTION}

Forestry or land use in general provides mankind with food, renewable energy and other specific supplies (Haberl et al., 2007; Millennium Ecosystem Assessment, 2005). While human population size and living standards continue to grow, but the amount of resources do not, we have to rely on sustainably intensified land use (Foley et al., 2011; Tilman et al., 2011). Forest management intensity determines to what extent related ecosystems are influenced, for example, intensified forestry production affects biogeochemical cycles (Luyssaert et al., 2012; Nabuurs et al., 2013), soils (Jandl et al., 2007), forest structure (Vilén et al., 2012) and biodiversity (Paillet et al., 2010).

Lately, low carbon footprint energy from renewable sources is taking increasing share of global energy supply (Whalen et al., 2017). In Latvia, the share of renewable energy resources in total consumed energy should reach $40 \%$ by 2020 (7.4\% increase compared to 2005), while in the whole European Union this share must reach $20 \%$ (European Parliament, 2009). One of the targets of European Commission's Bioeconomy Strategy and Action Plan is to use renewable biological resources sustainably while taking into account environmental and biodiversity protection including bioenergy from forestry (European Comission, 2012).

Timber is often considered as the most valuable resource in forestry, but logging residues consisting of branches, bark, stems and roots (lower value biomass) also make up significant energy source (Castro et al., 2017). Amid the recent decade in Nordic and Baltic countries stump harvesting has become more popular in forest management (Grelle et al., 2012; Lazdins et al., 2009; Persson, 2013; Uri et al., 2015), and as much as 140-200 MWh hal can be harvested (Hakkila,

Copyright (C) 2017 The Authors. Published by Aleksandras Stulginskis University. This is an open-access article distributed under the terms of the Creative Commons Attribution License (CC-BY 4.0), which permits unrestricted use, distribution, and reproduction in any medium, provided the original author and source are credited. 
2004; Hakkila Pentti, 2004). Lower value biomass removal can also reduce costs associated with site preparation for reforestation by removing excess debris (Barker et al., 2014; Fielding et al., 2012).

On the other hand, harvest of logging residues may cause increased nutrient removal from the site because of higher nutrient content in foliage and branches (Abbas et al., 2011; Hopmans and Elms, 2009; Tamminen et al., 2012; Walmsley et al., 2009). Leftover biomass may either serve as nutrient source or act as nutrient sink while decomposing (Barber and Van Lear, 1984; Devine et al., 2012; Strahm et al., 2005) and logging residues also play important role in determining soil microclimate and influence vegetation (Achat et al., 2015; Thiffault et al., 2011). Soil disturbance related to lower value biomass harvesting is mostly affecting top layers of soil (Carter and McDonald, 1998). Removal of whole tree biomass, taking into account the logistics, may significantly influence biological diversity and water quality in the site (Freedman et al., 1996; Harmon et al., 1986).

Considering these concerns, research is in progress to evaluate different scenarios of lower value biomass extraction from different forest type clearcuts considering environmental and forest regeneration aspects to optimize forestry activities.

\section{MATERIALS AND METHODS}

The study area is located in eastern part of Latvia in experimental forests of Kalsnava Forest district (Figure 1.). Climate is continental compared to other regions of Latvia (according to Jaunkalsnava meteorological station data situated $10 \mathrm{~km}$ distant). The annual precipitation amount was $1,023 \mathrm{~mm}$ in 2012, $590 \mathrm{~mm}$ in 2013, $823 \mathrm{~mm}$ in $2014,688 \mathrm{~mm}$ in 2015 and $694 \mathrm{~mm}$ in 2016 with largest share (61-74\%) falling as rain from April to October. Mean annual air temperature was $4.4{ }^{\circ} \mathrm{C}$ in $2012,5.1{ }^{\circ} \mathrm{C}$ in $2013,5.0^{\circ} \mathrm{C}$ in $2014,5.9^{\circ} \mathrm{C}$ in 2015 and $5.9^{\circ} \mathrm{C}$ in 2016.

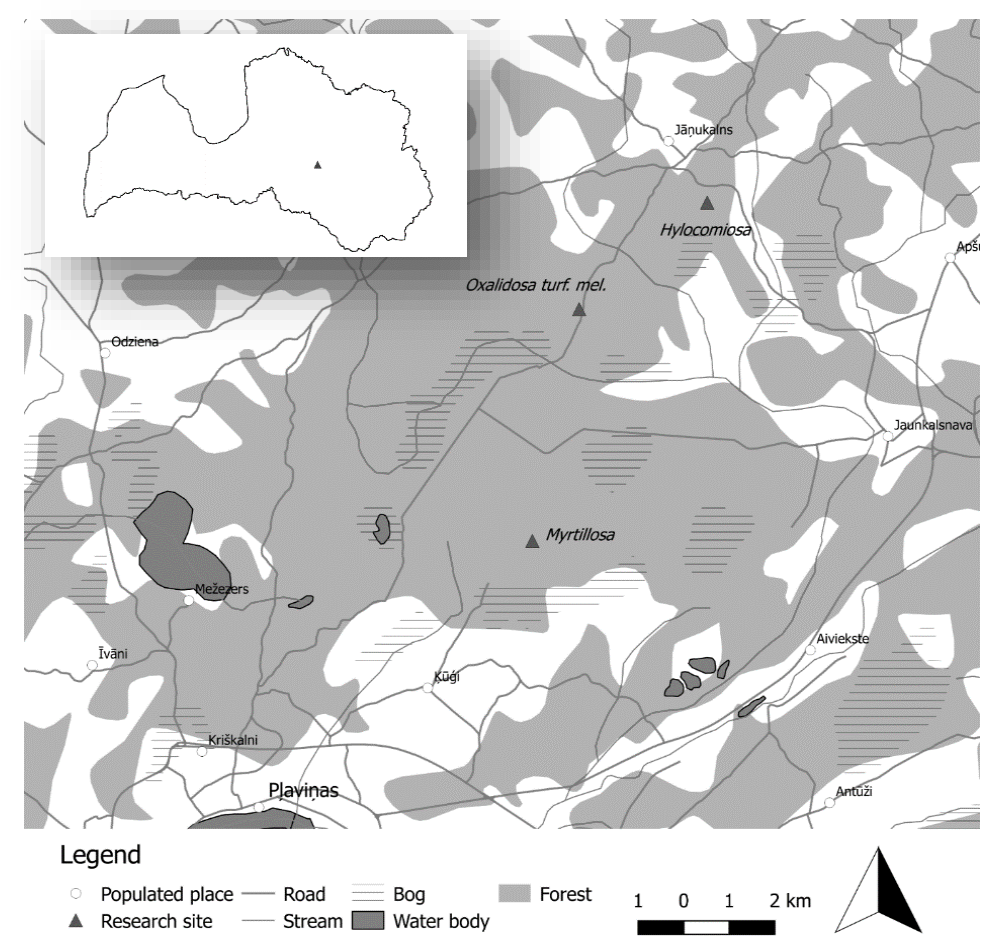

Figure 1. Location of research sites.

Research is carried out at three sites: two are located on mineral soils - Myrtillosa and Hylocomiosa site type, dominant tree species Pinus sylvestris L.; one on drained peat soil - Oxalidosa turf. mel. site type, dominant tree species Picea abies (L.) Karst. Drainage systems were made in 1960. All sites are located on slopes - $5^{\circ}$ in Oxalidosa turf.mel., $15^{\circ}$ in Hylocomiosa and Myrtillosa, with bufferzone in the lower part. Site description is given in Table 1.

Table 1. Description of the study sites

\begin{tabular}{llcccc}
\hline Site & Dominant tree species & $\begin{array}{c}\text { Mean diameter, } \\
\mathrm{cm}\end{array}$ & $\begin{array}{c}\text { Mean eight, } \\
m\end{array}$ & $\begin{array}{c}\text { Basal area, } \\
\mathrm{m}^{2} h a^{-1}\end{array}$ & $\begin{array}{c}\text { Standing volume before felling, } \\
\mathrm{m}^{3} \mathrm{~h}^{-1}\end{array}$ \\
\hline Hylocomiosa & Pinus sylvestris L. & 34 & 31 & 35.3 & 541.3 \\
Oxalidosa & Picea abies L. & & & & 315.0 \\
turf.mel. & (Karst.) & 31 & 25 & 17.4 & 270.9 \\
Myrtillosa & Pinus sylvestris L. & 31 & 26 & 21.2 & \\
\hline
\end{tabular}


At each site, three sampling plots were established: whole tree harvesting (WTH, only above-ground biomass harvested), stem-only harvesting (SOH) and control (C). Size of the plot varied from 3.00 to 3.75 ha. Three pairs of suction tube lysimeters (lysimeter cup made of porous ceramic - $92 \%$ pure $\mathrm{Al}_{2} \mathrm{O}_{3}$ and body of trace metal-free PVC) at 2 depths (30 and $60 \mathrm{~cm}$ ) per sample plot were installed in autumn 2011. Water samples were collected twice per month during the vegetation season in 2012 (reference period), 2013, and 2014 (first and second years following regeneration felling), after that in 2015 and 2016 samples were collected once per month. Regeneration felling was performed in early spring 2013 with harvester, timber was extracted and logging residues were removed with forwarder, following 'business as usual' principle. During harvest the soil was frozen, and no damage to the soil due to the movement of machinery was observed. At the wholetree harvested plots all above-ground part of the tree was harvested (in practice this means that approximately $70 \%$ of tree tops and branches were removed). At the stem-only harvested plots only the stemwood was removed and logging residues were evenly scattered throughout the plot. Sample and data collection from the sites is planned till year 2020.

The soil solution deposition samples were analyzed in the Forest Environment Laboratory at the LSFRI Silava. The following chemical parameters were measured in the water samples: $\mathrm{pH}$ determined according to LVS ISO 10523:2012, nitrate-nitrogen $\left(\mathrm{NO}_{3}{ }^{-}-\mathrm{N}\right)$ concentration determined using FORMACSHT TOC/TN Analyzer (ND25 nitrogen detector); phosphate-phosphorus $\left(\mathrm{PO}_{4}{ }^{3-}-\mathrm{P}\right)$ determined using an ammonium molybdate spectrometric method according to ISO 6878 and potassium (K) determined using a flame emission spectrometric method according to ISO 9964-3:2000. Preservation and handling of water samples were done according to ISO 5667-3:2012.

\section{RESULTS}

Mean annual soil solution $\mathrm{pH}$ at $\mathrm{C}, \mathrm{SOH}$ and $\mathrm{WTH}$ plots of all three sites before (in 2012) and after regeneration felling (in 2013-2016) are shown in Figure 2. During research period most alkaline soil solution was found in $\mathrm{C}$ and $\mathrm{SOH}$ plots in Oxalidosa turf. mel. site (mean annual soil solution $\mathrm{pH}$ values ranged from $7.30 \pm 0.04$ to $7.72 \pm 0.05$ ) that indirectly indicates the presence of confined aquifer discharge water input rich in carbonates. The most acidic soil solution was found in SOH plot in Myrtillosa site in the second, third, and fourth year after treatment (mean annual soil solution $\mathrm{pH}$ ranged from $5.07 \pm 0.12$ to $5.25 \pm 0.13$ ). In $\mathrm{C}$ plots, significant changes in soil solution $\mathrm{pH}$ during research period were not detected. Conversely, gradual $\mathrm{pH}$ value decrease in the soil solution after felling was observed nearly at all harvested plots, except the SOH plot in Oxalidosa turf. mel. site where decrease in the soil solution pH was not observed. Comparing mean annual soil solution $\mathrm{pH}$ before regeneration felling (in 2012) and after felling (in 2013-2016), the most significant decrease of mean annual soil solution $\mathrm{pH}$ value (by $1.7 \mathrm{pH}$ units) after felling was observed in SOH plot in Myrtillosa site in 2016 (in the fourth year after treatment). Comparing mean annual soil solution $\mathrm{pH}$ after felling in SOH and WTH plots in Myrtillosa site, a more pronounced decrease of mean annual soil solution pH value was observed in the plot where logging residues were left on site (SOH plot). Conversely, in Oxalidosa turf. mel. site, mean annual soil solution pH value decreased only in WTH plot; furthermore, the most significant decrease of mean annual soil solution $\mathrm{pH}$ value was observed in the second year after felling. In Hylocomiosa site, mean annual soil solution $\mathrm{pH}$ value was not significantly affected by removal of logging residues (tree tops and branches), if compared to SOH plot.

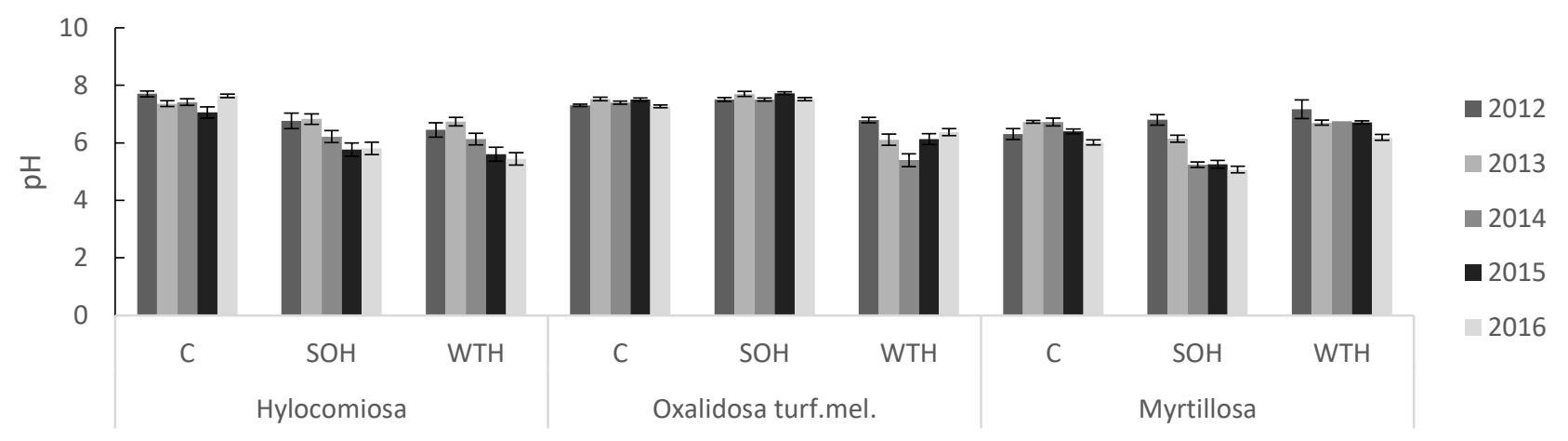

Figure 2. Mean annual soil solution $\mathrm{pH}$ at the study sites. Error bars represent standard error.

Mean annual $\mathrm{NO}_{3}^{-}-\mathrm{N}$ concentrations in soil solution at $\mathrm{C}, \mathrm{SOH}$ and $\mathrm{WTH}$ plots of all three sites are shown in Figure 3. During research period mean annual $\mathrm{NO}_{3}^{-}-\mathrm{N}$ concentrations in soil solution ranged up to $10.7 \pm 1.6 \mathrm{mg} \mathrm{L}^{-1}$. Although some significant differences of mean annual $\mathrm{NO}_{3}{ }^{-}-\mathrm{N}$ concentration in soil solution between plots were observed before regeneration felling (in 2012), mostly results show significant impact of felling on mean annual $\mathrm{NO}_{3}^{-}-\mathrm{N}$ concentration in soil solution. The most elevated $\mathrm{NO}_{3}{ }^{-}-\mathrm{N}$ concentrations in soil solution were observed in the second and third year after felling (in 2014 and 2015), but in the third and fourth year after felling, depending on the site, mean annual $\mathrm{NO}_{3}{ }^{-}-\mathrm{N}$ concentration in soil solution started to decrease or even reached pre-felling levels. On the contrary to all other harvested plots, at $\mathrm{SOH}$ plot in Oxalidosa turf. mel. site increase of mean annual $\mathrm{NO}_{3}{ }^{-}-\mathrm{N}$ concentration in soil solution after felling was not observed and also increase of mean annual $\mathrm{NO}_{3}{ }^{-}-\mathrm{N}$ concentration in soil solution after felling in WTH plot in Myrtillosa site was negligible. 


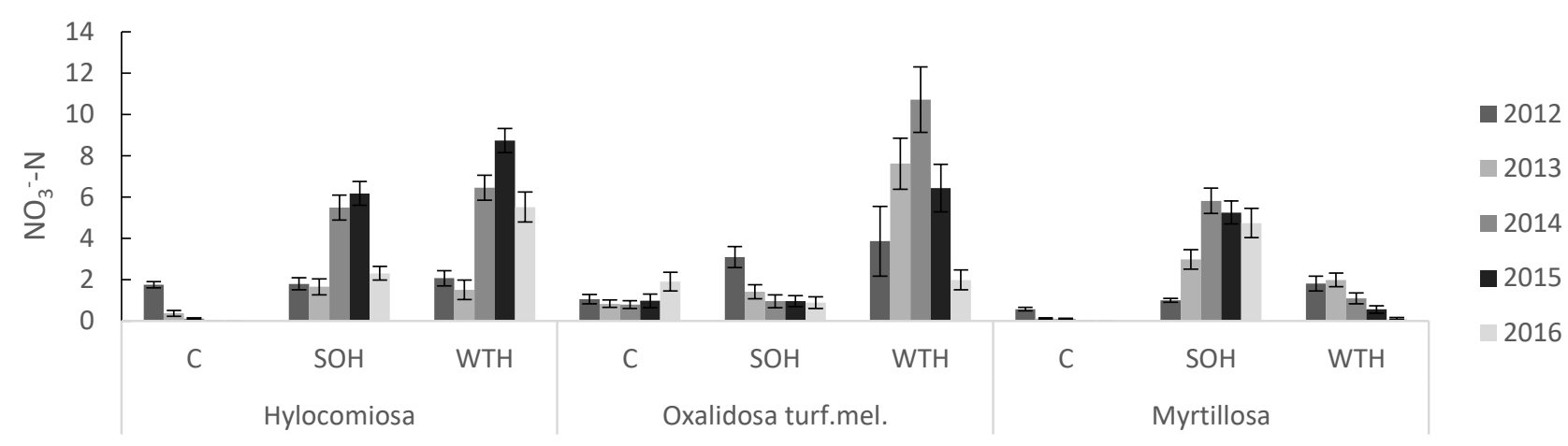

Figure 3. Mean annual $\mathrm{NO}_{3}-\mathrm{N}$ concentration in soil solution at the study sites. Error bars represent standard error.

Mean annual $\mathrm{PO}_{4}{ }^{3-}-\mathrm{P}$ concentration in soil solution at $\mathrm{C}, \mathrm{SOH}$ and WTH plots of all three sites are shown in Figure 4. During research period mean annual $\mathrm{PO}_{4}{ }^{3-}-\mathrm{P}$ concentration in soil solution ranged up to $0.09 \pm 0.04 \mathrm{mg} \mathrm{L^{-1 }}$. Significant impact of regeneration felling on $\mathrm{PO}_{4}{ }^{3-}-\mathrm{P}$ concentration in soil solution was not observed. However, elevated $\mathrm{PO}_{4}{ }^{3-}-\mathrm{P}$ concentrations in soil solution were observed in 2016, on the fourth year after felling, at WTH plots in Hylocomiosa and Oxalidosa turf. mel. sites.

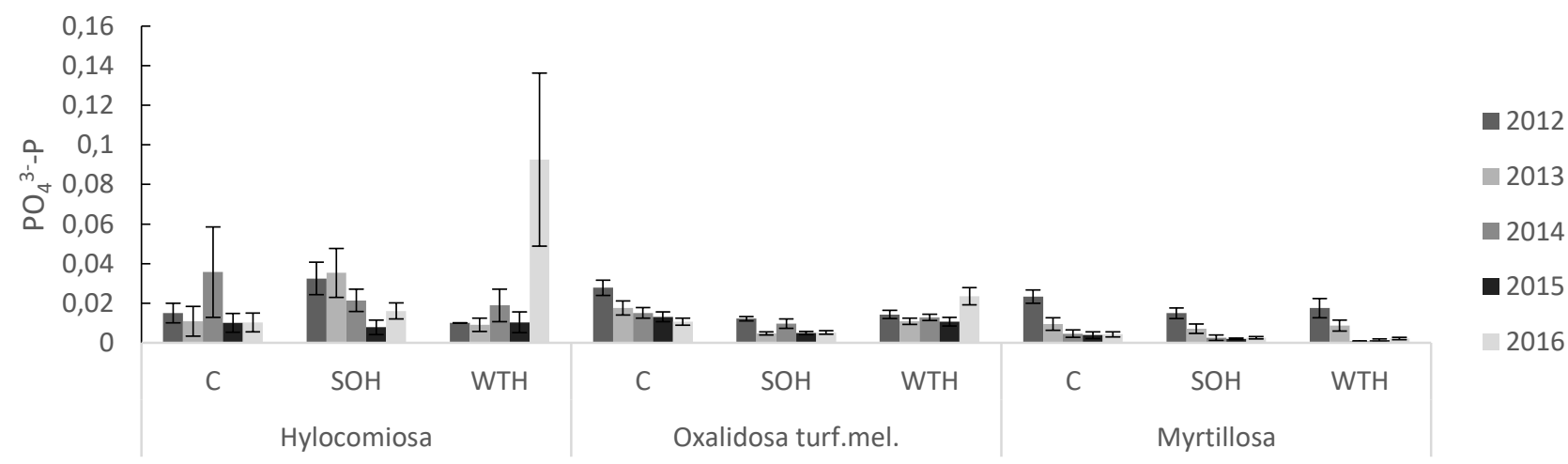

Figure 4. Mean annual $\mathrm{PO}_{4}{ }^{3-}-\mathrm{P}$ concentration in soil solution at the study sites. Error bars represent standard error.

In Figure 5, mean annual $\mathrm{K}$ concentration in soil solution at $\mathrm{C}, \mathrm{SOH}$ and $\mathrm{WTH}$ plots of all three sites are shown. During research period, mean annual $\mathrm{K}$ concentration in soil solution ranged up to $6.6 \pm 0.7 \mathrm{mg} \mathrm{L}^{-1}$. On average, the highest $\mathrm{K}$ concentrations in soil solution were observed in Hylocomiosa site, but the lowest in $\mathrm{C}$ and SOH plots in Oxalidosa turf. mel. site. Trends in $\mathrm{K}$ concentration in soil solution after regeneration felling are similar to the changes in $\mathrm{NO}_{3}^{-}-\mathrm{N}$ concentration in soil solution. Elevated $\mathrm{K}$ concentrations in soil solution were observed in the first and second year after felling at SOH and WTH plots in Hylocomiosa site, at WTH plot in Oxalidosa turf. mel. site and SOH site in Myrtillosa site. In the all mentioned plots, peak $\mathrm{K}$ concentrations in soil solution were observed in the second year after felling (in 2014), but in the third and fourth year after felling K concentrations in soil solution started to decrease.

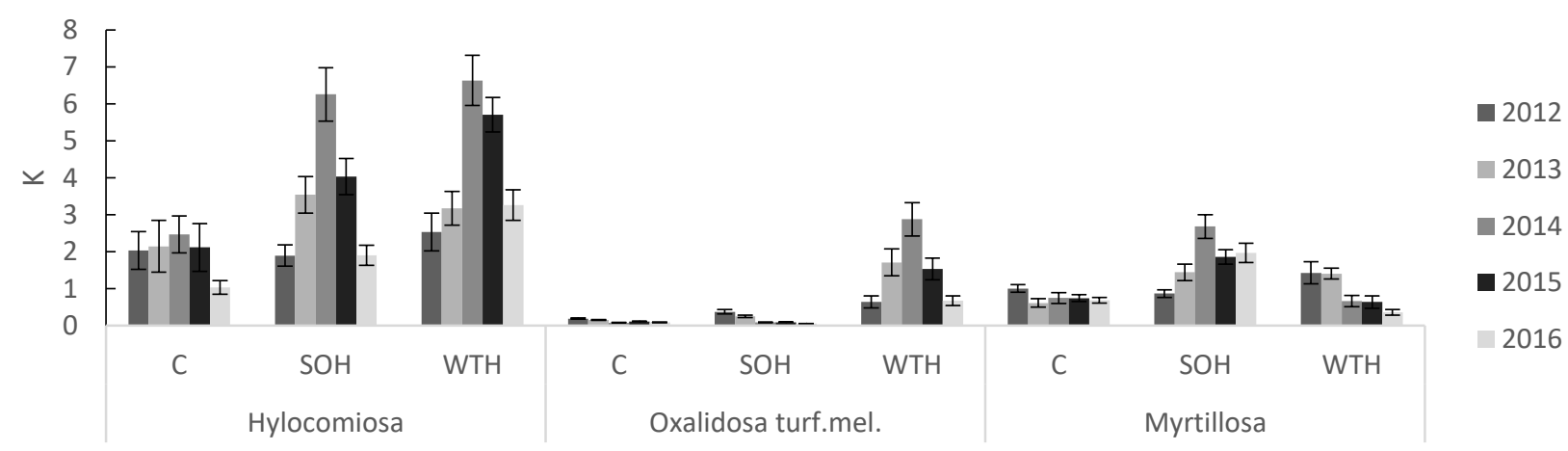

Figure 5. Mean annual K concentration in soil solution at the study sites. Error bars represent standard error.

\section{CONCLUSIONS AND DISCUSSION}

The effect of biomass harvesting on soil solution chemical composition and leaching of nutrients has been followed in numerous studies since the late 1960s, where the classic experiments at the Hubbard Brook Experimental Forest (HBEF) USA (Likens et al., 1970) illustrated the dramatic increase in leaching of nutrients from a catchment scale clear- 
cut. In general, the nutrient concentration in soil waters increase with peak nutrient concentrations within 2-3 years after clear-cut. The nutrient concentration often returns to pre-cutting levels within relatively short time, normally 3-5 years, especially if clear-cut is performed without any other disturbances (Raulund-Rasmussen et al., 2011). Even if soil-water chemistry is affected by the residue treatments, the response tends to differ between the sites (Ring et al., 2015).

We detected a strong response in nutrient concentrations following regeneration felling in the all three sites (except SOH plot in Oxalidosa turf. mel. site and WTH plot in Myrtillosa site). Results of our study confirm that $\mathrm{NO}_{3}^{-}-\mathrm{N}^{-}$and K concentration in soil solution peak after 2-3 years and are back to pre-treatment levels after 3-4 years. Whole tree harvest impact on $\mathrm{pH}$ value is greater on soils with lower buffer capacity and shallow soils (Löfgren et al., 2017), which is the reason why significant $\mathrm{pH}$ value change in Oxalidosa turf. mel. site was not detected due to alkaline underground pressure water input. In Myrtillosa and Hylocomiosa site $\mathrm{pH}$ value dropped after clearcutting. Nitrate, phosphate and potassium concentrations generally increased after clearcutting due to leaching, but in 2015 and 2016 already tend to reach for values observed in the pre-treatment period.

Whole tree harvesting technique may cause growth reduction in first 8-year period for the next generation (Egnell and Ulvcrona, 2015) although change in site yield capacity and total amount of nutrients in the soil and forest floor are usually small (Brandtberg and Olsson, 2012). Lower value biomass removal may affect recovery speed of the site more intensively on acidic soils (Akselsson and Belyazid, 2018). On sandy soils macronutrient regeneration intensity by weathering and deposition may not provide enough for whole tree harvesting in long term (Vangansbeke et al., 2015). These factors will be further evaluated in the research sites.

\section{ACKNOWLEDGEMENTS}

In this publication data from the research programme "The impact of forest management on ecosystem services provided by forests and related ecosystems", implemented by LSFRI "Silava" with financial and technical support from JSC "Latvia's State Forests", are used.

\section{REFERENCES}

1. Abbas, D., Current, D., Phillips, M., Rossman, R., Hoganson, H., Brooks, K.N. 2011. Guidelines for harvesting forest biomass for energy: A synthesis of environmental considerations. Biomass and Bioenergy, Vol. 35, pp. $4538-4546$. https://doi.org/10.1016/j.biombioe.2011.06.029

2. Achat, D.L., Deleuze, C., Landmann, G., Pousse, N., Ranger, J., Augusto, L. 2015. Quantifying consequences of removing harvesting residues on forest soils and tree growth - A meta-analysis. Forest Ecology and Management, Vol. 358, pp. 124-141. https://doi.org/10.1016/j.foreco.2015.03.042

3. Akselsson, C., Belyazid, S. 2018. Critical biomass harvesting - Applying a new concept for Swedish forest soils. Forest Ecology and Management, Vol. 409, pp. 67-73. https://doi.org/10.1016/j.foreco.2017.11.020

4. Barber, B.L., Van Lear, D.H. 1984. Weight Loss and Nutrient Dynamics in Decomposing Woody Loblolly Pine Logging Slash1. Soil Science Society of America Journal, Vol. 48, pp. 906-910. https://doi.org/10.2136/sssaj1984.03615995004800040041x

5. Barker, J.S., Simard, S.W., Jones, M.D. 2014. Clearcutting and high severity wildfire have comparable effects on growth of directseeded interior Douglas-fir. Forest Ecology and Management, Vol. 331, pp. 188-195. https://doi.org/10.1016/j.foreco.2014.08.004

6. Brandtberg, P.O., Olsson, B.A. 2012. Changes in the effects of whole-tree harvesting on soil chemistry during 10years of stand development. Forest Ecology and Management, Vol. 277, pp. 150-162. https://doi.org/10.1016/j.foreco.2012.04.019

7. Carter, E.A., McDonald, T.P. 1998. Interaction among machine traffic, soil physical properties and Loblolly pine root proliferation in a piedmont soil. Ninth Biennial Southern Silviculture Conference pp. 368-372.

8. Castro, A.F.N.M., Castro, R.V.O., Carneiro, A. de C.O., Carvalho, A.M.M.L., da Silva, C.H.F., Cândido, W.L., dos Santos, R.C. 2017. Quantification of forestry and carbonization waste. Renewable Energy, Vol. 103, pp. $432-438$. https://doi.org/10.1016/j.renene.2016.11.050

9. Devine, W.D., Footen, P.W., Strahm, B.D., Harrison, R.B., Terry, T.A., Harrington, T.B. 2012. Nitrogen leaching following wholetree and bole-only harvests on two contrasting Pacific Northwest sites. Forest Ecology and Management, Vol. 267, pp. 7-17. https://doi.org/10.1016/j.foreco.2011.11.043

10. Egnell, G., Ulvcrona, K.A. 2015. Stand productivity following whole-tree harvesting in early thinning of Scots pine stands in Sweden. Forest Ecology and Management, Vol. 340, pp. 40-45. https://doi.org/10.1016/i.foreco.2014.12.017

11. European Comission. 2012. Commission adopts its Strategy for a sustainable bioeconomy to ensure smart green growth in Europe. Statistics (Ber). Available at http://europa.eu/rapid/press-release_MEMO-12-97_en.htm?locale=en (Accessed on 10/12/2014)

12. European Parliament. 2009. Directive 2009/28/EC of the European Parliament and of the Council of 23 April 2009. Official Journal of the European Union, Vol. 140, pp. 16-62.

13. Fielding, D., Cubbage, F., Peterson, M.N., Hazel, D., Gugelmann, B., Moorman, C. 2012. Opinions of Forest Managers, Loggers, and Forest Landowners in North Carolina regarding Biomass Harvesting Guidelines. International Journal of Forestry Research, Vol. 2012, pp. 1-15. https://doi.org/10.1155/2012/256141

14. Foley, J.A., Ramankutty, N., Brauman, K.A., Cassidy, E.S., Gerber, J.S., Johnston, M., Mueller, N.D., O’Connell, C., Ray, D.K., West, P.C., Balzer, C., Bennett, E.M., Carpenter, S.R., Hill, J., Monfreda, C., Polasky, S., Rockström, J., Sheehan, J., Siebert, S., Tilman, D., Zaks, D.P.M. 2011. Solutions for a cultivated planet. Nature, Vol. 478, pp. $337-342$. https://doi.org/10.1038/nature10452

15. Freedman, B., Zelazny, V., Beaudette, D., Fleming, T., Johnson, G., Flemming, S., Gerrow, J.S., Forbes, G., Woodley, S. 1996. Biodiversity implications of changes in the quantity of dead organic matter in managed forests. Environmental Reviews, Vol. 4 , pp. 238-265. https://doi.org/10.1139/a96-013 
16. Grelle, A., Strömgren, M., Hyvönen, R. 2012. Carbon balance of a forest ecosystem after stump harvest. Scandinavian Journal of Forest Research, Vol. 27, pp. 762-773. https://doi.org/10.1080/02827581.2012.726371

17. Haberl, H., Erb, K.H., Krausmann, F., Gaube, V., Bondeau, A., Plutzar, C., Gingrich, S., Lucht, W., Fischer-Kowalski, M., 2007. Quantifying and mapping the human appropriation of net primary production in earth's terrestrial ecosystems. Proceedings of the National Academy of Sciences, Vol. 104, pp. 12942-12947. https://doi.org/10.1073/pnas.0704243104

18. Hakkila, P. 2004. Developing technology for large-scale production of forest chips, Technology Programme Report, Vol. 6, pp 102.

19. Hakkila P. Aarniala, M. 2004. Stumps - an unutilised reserve. Wood Energy Technology Programme Newsletter on results 4/2004 2.

20. Harmon, M.E., Franklin, J.F., Swanson, F.J., Sollins, P., Gregory, S.V., Lattin, J.D., Anderson, N.H., Cline, S.P., Aumen, N.G., Sedell, J.R., Lienkaemper, G.W., Cromack, K.J., Cummins, K.W. 1986. Ecology of Course Woody Debris in Temperate Ecosystems. Advances in Ecological Research, Vol. 15, pp. 133-320. https://doi.org/10.1016/S0065-2504(08)60121-X

21. Hopmans, P., Elms, S.R. 2009. Changes in total carbon and nutrients in soil profiles and accumulation in biomass after a 30-year rotation of Pinus radiata on podzolized sands: Impacts of intensive harvesting on soil resources. Forest Ecology and Management, Vol. 258, pp. 2183-2193. https://doi.org/10.1016/j.foreco.2009.02.010

22. Jandl, R., Lindner, M., Vesterdal, L., Bauwens, B., Baritz, R., Hagedorn, F., Johnson, D.W., Minkkinen, K., Byrne, K.A. 2007. How strongly can forest management influence soil carbon sequestration? Geoderma, Vol. 137, pp. $253-268$. https://doi.org/10.1016/i.geoderma.2006.09.003

23. Lazdins, A., Hofsten, H. Von, Dagnija, L., Valentins, L. 2009. Productivity and Costs of Stump Harvesting for Bioenergy Production in Latvian Conditions. International Scientific Conference: Engineering for Rural Development, pp. 194-201.

24. Likens, G.E., Bormann, F.H., Johnson, N.M., Fisher, D.W., Pierce, R.S. 1970. Effects of Forest Cutting and Herbicide Treatment on Nutrient Budgets in the Hubbard Brook Watershed-Ecosystem. Ecological Monographs 40, pp. $23-47$. https://doi.org/10.2307/1942440

25. Löfgren, S., Ågren, A., Gustafsson, J.P., Olsson, B.A., Zetterberg, T. 2017. Impact of whole-tree harvest on soil and stream water acidity in southern Sweden based on HD-MINTEQ simulations and $\mathrm{pH}$-sensitivity. Forest Ecology and Management, Vol. 383, pp. 49-60. https://doi.org/10.1016/i.foreco.2016.07.018

26. Luyssaert, S., Abril, G., Andres, R., Bastviken, D., Bellassen, V., Bergamaschi, P., Bousquet, P., Chevallier, F., Ciais, P., Corazza, M., Dechow, R., Erb, K.H., Etiope, G., Fortems-Cheiney, A., Grassi, G., Hartmann, J., Jung, M., Lathière, J., Lohila, A., Mayorga, E., Moosdorf, N., Njakou, D.S., Otto, J., Papale, D., Peters, W., Peylin, P., Raymond, P., Rödenbeck, C., Saarnio, S., Schulze, E.D., Szopa, S., Thompson, R., Verkerk, P.J., Vuichard, N., Wang, R., Wattenbach, M., Zaehle, S. 2012. The European land and inland water $\mathrm{CO} 2, \mathrm{CO}, \mathrm{CH} 4$ and $\mathrm{N} 2 \mathrm{O}$ balance between 2001 and 2005. Biogeosciences, Vol. 9, pp. 3357-3380. https://doi.org/10.5194/bg-9-3357-2012

27. Millennium Ecosystem Assessment, 2005. Ecosystems and Human well-being. Synthesis. Washington, Vol. 5, pp. 155.

28. Nabuurs, G.-J., Lindner, M., Verkerk, P.J., Gunia, K., Deda, P., Michalak, R., Grassi, G. 2013. First signs of carbon sink saturation in European forest biomass. Nature Climate Change, Vol. 3, pp. 792-796. https://doi.org/10.1038/nclimate1853

29. Paillet, Y., Bergès, L., HjÄltén, J., Ódor, P., Avon, C., Bernhardt-Römermann, M., Bijlsma, R.J., De Bruyn, L., Fuhr, M., Grandin, U., Kanka, R., Lundin, L., Luque, S., Magura, T., Matesanz, S., Mészáros, I., SebastiÀ, M.T., Schmidt, W., Standovár, T., TÓthmérész, B., Uotila, A., Valladares, F., Vellak, K., Virtanen, R. 2010. Biodiversity differences between managed and unmanaged forests: Meta-analysis of species richness in Europe. Conservation Biology, Vol. 24, Iss. 1, pp. $101-112$. https://doi.org/10.1111/j.1523-1739.2009.01399.x

30. Persson, T. 2013. Environmental consequences of tree-stump harvesting. Forest Ecology and Management, Vol. 290 , pp. 1-4. https://doi.org/10.1016/j.foreco.2012.09.024

31. Raulund-Rasmussen, K., De Jong, J., Humphrey, J.W., Smith, M., Ravn, H.P., Katzensteiner, K., Klimo, E., Szukics, U., Delaney, C., Hansen, K., Stupak, I., Ring, E., Gundersen, P., Loustau, D. 2011. Papers on impacts of forest management on environmental services. European Forest Institute Techincal Report, Vol. 57, pp. 1-139.

32. Ring, E., Högbom, L., Nohrstedt, H.Ö., Jacobson, S. 2015. Soil and soil-water chemistry below different amounts of logging residues at two harvested forest sites in Sweden. Silva Fennica, Vol. 49. https://doi.org/10.14214/sf.1265

33. Strahm, B.D., Harrison, R.B., Terry, T.A., Flaming, B.L., Licata, C.W., Petersen, K.S. 2005. Soil solution nitrogen concentrations and leaching rates as influenced by organic matter retention on a highly productive Douglas-fir site. Forest Ecology and Management, Vol. 218, pp. 74-88. https://doi.org/10.1016/j.foreco.2005.07.013

34. Tamminen, P., Saarsalmi, A., Smolander, A., Kukkola, M., Helmisaari, H.S. 2012. Effects of logging residue harvest in thinnings on amounts of soil carbon and nutrients in Scots pine and Norway spruce stands. Forest Ecology and Management, Vol. 263, pp. 31-38. https://doi.org/10.1016/j.foreco.2011.09.015

35. Thiffault, E., Hannam, K.D., Paré, D., Titus, B.D., Hazlett, P.W., Maynard, D.G., Brais, S. 2011. Effects of forest biomass harvesting on soil productivity in boreal and temperate forests - A review. Environmental Reviews, Vol. 19, pp. $278-309$. https://doi.org/10.1139/a11-009

36. Tilman, D., Balzer, C., Hill, J., Befort, B.L. 2011. Global food demand and the sustainable intensification of agriculture. Proceedings of the National Academy of Sciences, Vol. 108, pp. 20260-20264. https://doi.org/10.1073/pnas.1116437108

37. Uri, V., Aosaar, J., Varik, M., Becker, H., Kukumägi, M., Ligi, K., Pärn, L., Kanal, A. 2015. Biomass resource and environmental effects of Norway spruce (Picea abies) stump harvesting: An Estonian case study. Forest Ecology and Management, Vol. 335, pp. 207-215. https://doi.org/10.1016/j.foreco.2014.10.003

38. Vangansbeke, P., De Schrijver, A., De Frenne, P., Verstraeten, A., Gorissen, L., Verheyen, K. 2015. Strong negative impacts of whole tree harvesting in pine stands on poor, sandy soils: A long-term nutrient budget modelling approach. Forest Ecology and Management, Vol. 356, pp. 101-111. https://doi.org/10.1016/j.foreco.2015.07.028

39. Vilén, T., Gunia, K., Verkerk, P.J., Seidl, R., Schelhaas, M.J., Lindner, M., Bellassen, V. 2012. Reconstructed forest age structure 
in Europe 1950-2010. Forest Ecology and Management, Vol. 286, pp. 203-218. https://doi.org/10.1016/j.foreco.2012.08.048

40. Walmsley, J.D., Jones, D.L., Reynolds, B., Price, M.H., Healey, J.R. 2009. Whole tree harvesting can reduce second rotation forest productivity. Forest Ecology and Management, Vol. 257, pp. 1104-1111. https://doi.org/10.1016/j.foreco.2008.11.015

41. Whalen, J., Xu, C., Shen, F., Kumar, A., Eklund, M., Yan, J. 2017. Sustainable biofuel production from forestry, agricultural and waste biomass feedstocks. Applied Energy, Vol. 198, pp. 281-283. https://doi.org/10.1016/j.apenergy.2017.05.079 